\title{
A STUDY OF CRITICAL DEPTH AND MODE OF SAND MOVEMENT USING RADIOACTIVE GLASS SAND
}

\author{
Shoji Sato, Takeshi Ijima and Norio Tanaka \\ Hydraulics Division, Harbor Technical Research Institute, \\ Ministry of Transportation, Yokosuka, Japan.

\section{INTRODUCTION}

In Japan, in order to get foundamental data for harbor construction planning, radioactive glass sand has been used on the coasts of Tomakomai Irako, Fukue, Isohama, Kashima and Niigata as shown in Figure 1. The authors have directed these field experiments excepting Tomakomai and been doing model experiments using radioactive glass sand.

The field observation of sand movement using radioactive tracers has been already performed in several contries of the world and many works have been published. Authors have aimed to make clear the direction of sand transport in several depths of water and the critical water depth of sand movement where harbors are to be constructed, in order to get basic data for the best arrengement of breakwaters on sandy beach. The activity of radioactive glass sand ( Co-60 and Sc-46) used at one point was several millicuries in the inland coast and several tens millicuries in the open coast.

In this paper, the qualitative characteristics of sand movement in the offshore and the breaker zone and the relations of waves, depth and bottom materials are estimated from the field experiments. Moreover, in the model test, the glass sand containing $\mathrm{Cr}-51$ was used in order to study the mode of sand movement due to waves, in particular, the direction of ripple movement and sand transport.

\section{THE PROPERTIES OF SAND MOVEMENT FROM FIELD EXXPERIMENTS}

\section{METHOD OF FIELD EXPERIMENT}

Preperation of radioactive glass sand The radioactive glass sand has mainly been made by irradiating glass sand containing cobalt or scandium in the nuclear reactor of Japan Atomic Rower Reseach Institute.

The weight ratio of materials for the glass sand containing cobalt used at Kashima Coast is shown as an example.

$$
\begin{array}{rllll}
\mathrm{SiO}_{2} & \mathrm{CaCO}_{3} & \mathrm{Na}_{2} \mathrm{CO} 3 & \mathrm{NaNO}_{3} & \mathrm{CO}_{2} \mathrm{O}_{3} \\
56.5 \% & 15.1 \% & 18.8 \% & 1.6 \% & 7.9 \%
\end{array}
$$

These materials are melted together in an electric furnance and glass of specific gravity 2.65 containing $6.8 \%$ of cobalt in weight is obtained. Then, it is crushed and seived to the required size and irradiated to have 80 microcuries of cobalt -60 per gram of glass sand. 
A STUDY OF CRITICAL DEPTH AND MODE OF SAND MOVEMENT USING RADIOACTIVE GLASS SAND

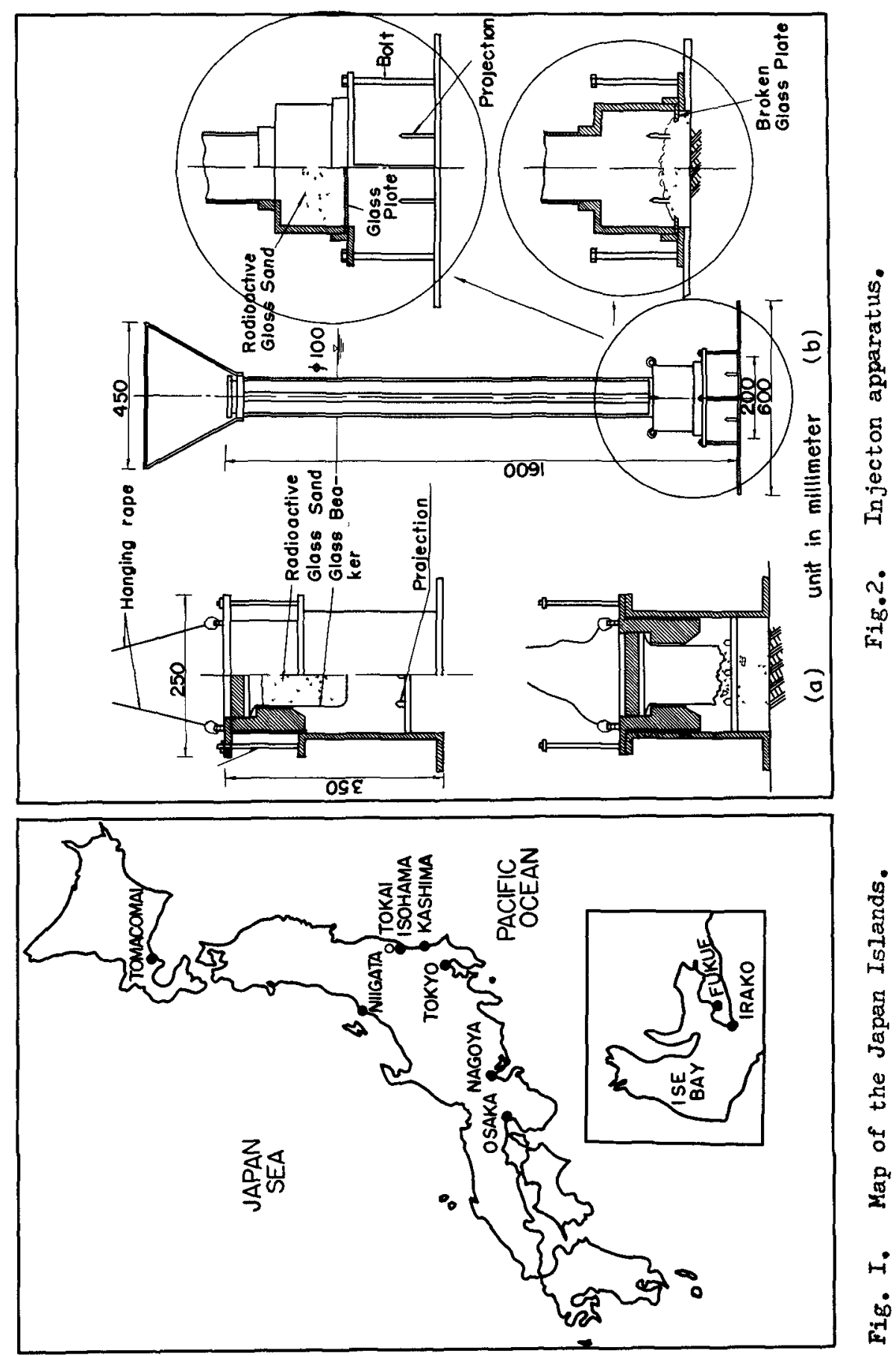




\section{COASTAL ENGINEERING}

Specific gravity is adjusted by changing the mixing weight ratio of $\mathrm{CaCO}_{3}$ and $\mathrm{Na}_{2} \mathrm{CO}_{5}$ or by addition of $\mathrm{Pb}_{3} \mathrm{O}_{4}$ and activity is adjusted by changing the containing ratio of cobalt. The glass sand of scandium46 is also made in the same way. The specific gravity of glass sand of our field experiments was all 2.65.

Injection of glass sand Eliminating the short life activities in three weeks or more after irradiation, the radioactive glass sand in polyechiren bags sheilded with lead container is carried to the site. The injection apparatus for small amount of glass sand is shown in Figure $2(\mathrm{a})$ and the one for large amount is in Figure $2(\mathrm{~b})$. The glass sand is poured into the injection apparatus through a funnel on the mouth of it by breaking the polyechiren bag of glass sand with a heated iron bar or a knife. Then, the injection apparatus is dropped down into sea with a rope. When. it touchs the sea bed, its upper portion drops down by its own weight and the bottom of teaker or the glass plate is broken by projections of the base. Thus, the glass sand is injected on the sea bed.

Tracing of plass sand The distribution of the glass sand injected on the bottom is traced by means of a watertight detection unit connected to a ratemeter with a cable. The detection unit contains Geiger-Muller tube or scintillation tube. The survey boat is fixed nearly the injection point with ancker ropes and then the detector is placed down on the sea bed. The tracing points of the detection unit is measured by transits on the beach. The distance of successive measuring points is usually about two to five meters. The counts per second measured by the detection unit, substracting the natural count, are protted on paper and equi-count-iines are drawn. At the same time, waves and currents are measured during the period of field experiment.

\section{THE SAND MOVEMENT IN THE OFFSHORE ZONE}

As the example of the field experiment in the offshore zone, the distributions of glass sand injected in the depth of 10 meters at Irako, 4.5 meters at Isohama, 9 meters at Kashima and 6.9 meters at Nilgata are shown in Figure 3, 4, 6, and 7 where the injection point, the distribution of equi-count lines and waves and currents are shown in that order. In these figures, depth counter lines are shown in meters below $L_{0}, W_{0}$. Waves are given at the depth of injection points and currents are those of one meter above sea bottom.

The experiment at Irako Irako Habor is situated at the entrance to Ise Bay, where the wind waves from NW-NWW prevail in winter. The tidal currents are so fast and the current velocity gets to about 60 centimeters per second in flood tide and the direction of tidal current is ESE during about twenty hours a day.

The results of this experiment are shown in Figure 3. The glass sand was moved toward ESE in accodance with the direction of tidal currents in flood tide, though the waves came from the direction of NW 


\section{A STUDY OF CRITICAL DEPTH AND MODE OF SAND MOVEMENT USING RADIOACTIVE GLASS SAND}

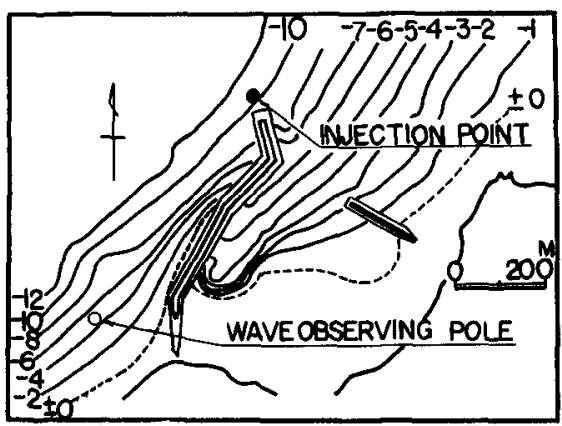

(a) Location of the Injection Point

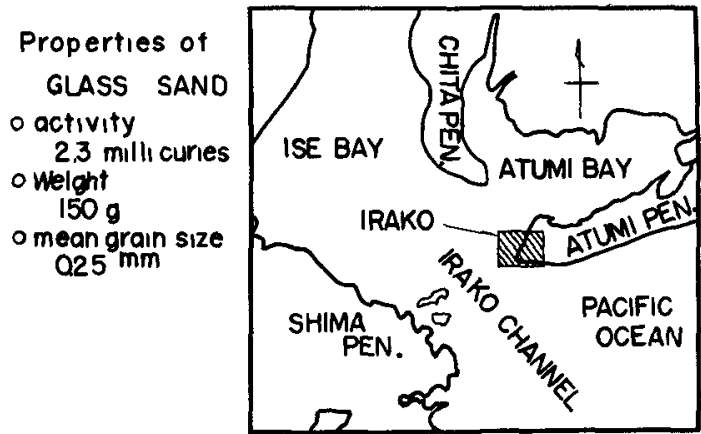

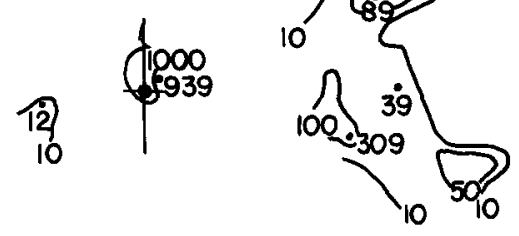

(1) Jan. 21 st in 1958 (2) Jan 26 th (The day of injection)

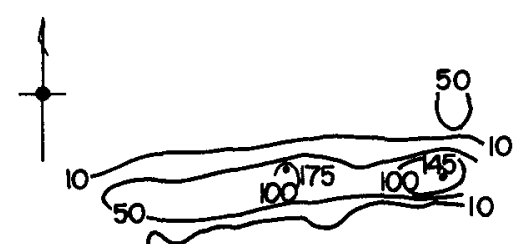

(3) Jan. 28 th
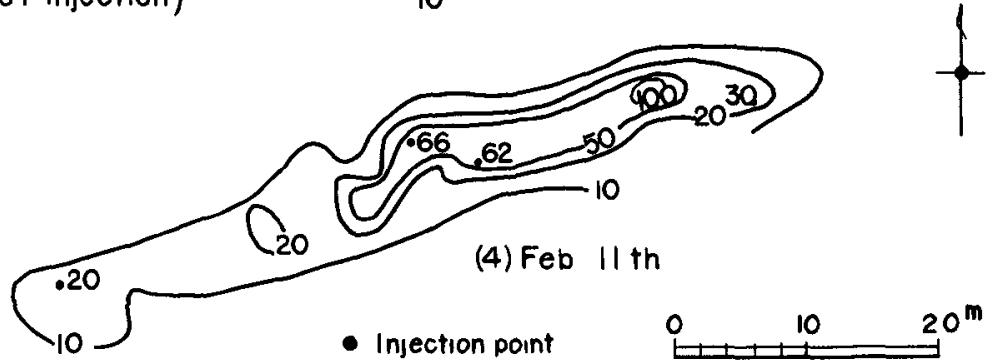

(b) Distribution of equi-count lines (unit cps)

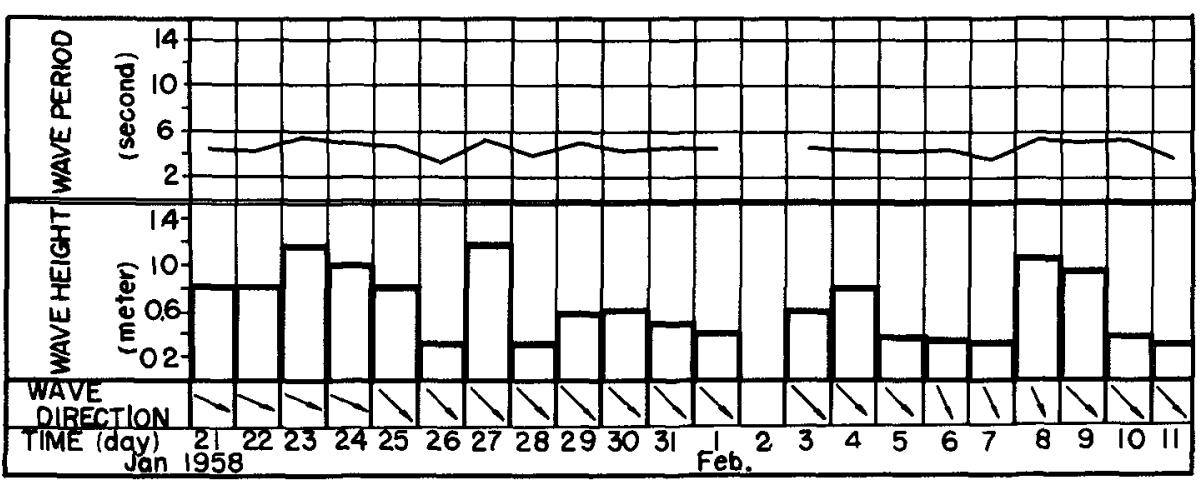

(c) Chracteristics of waves

Fig. 3. Experiment at Io meters deep of Irako. 


\section{COASTAL ENGINEERING}

and NNW during this experiment and the maximum significant wave height was 1.2 weters.

The experiment at Isohama Coast Isohana Coast is on the Pacific Ocean, where the velocity of tidal current one meter above the sea bottom is about 3 5 centimeters per second on calm day. The result of experiment is shown in Figure 4. It is seen from the measurement of the injection day that a part of glass sand at first moved toward ESE in accordance with the current direction, and opposite to the wave direction. After that, glass sand was dispersed toward WNW due to the wave of Nov. 20th and that of from $23 \mathrm{rd}$ to 27 th which were 1.4 and 2.3 meters in the maximum significant wave height, respectively. On the measurement after the waves on Dec. 6 th of 2.6 meters in the maximum height and 12 second in period, the glass sand could not be detected anywhere except at the injection point. In the above distributions, equi-count lines distribute closer in its onshore side than in its offshore side. This may be considered to show that a part of glass sand suspended by waves was flowed in the offshore direction by underwater currents.

Then, on Jan 18th in, 1960 the undisturbed bottom samples were taken by a diver with the cylinder of 6 centimeters in diameter and 30 centimeters long and the vertical distributions of glass sand were measured by scintillation counter. From the result shown in Figure 5, it is known that most of the glass sand distribute vertically from the bottom surface to only five centimeters deep.

The experiment at Kashimanada Caast Kashimanada Coast is also on the Pacific Ocean. An example of the experiment at 9 meters deep of this coast is shown in Figure 6. It is known from the measurement of the injection day that a part of glass sand was at first moved in the direction of currents. The result of measurement on March 3rd after the waves of 1.5 meters in height and 10 second in period shows that the glass sand dispersed in the same degree in the direction of both wave and current. Moreover, as seen from the measurement on March 27th, the glass sand was transported shoreward in accordance with the direction of the waves of March 21st and 22nd, of which the maximum significant wave was 2.5 meters in height and 10 second in period. The equi-count lines is closer in the north side than in the south side in these distributions of glass sand. This seems to show that the predominant direction of tidal currents was toward the south during this experiment.

The experiment at Niigata Coast Niigata Coast is on the Japan Sea, where it is calm in summer and stormy in winter. The results of tracing of glass sand injected in 7 meters deep is shown in Figure 7. A part of glass sand was transported in the direction of SN by tidal currents until July 18th. In the measurements on July $23 \mathrm{rd}$ after waves of 0.9 meters in height came from the NNW, the glass sand dispersed in the same degree both shoreward and seaward. Moreover, in the distribution of glass sand after the waves of 2.3 meters high, the point of the maximum counts was apart from the injection point 
A STUDY OF CRITICAL DEPTH AND MODE OF SAND MOVEMENT USING RADIOACTIVE

GLASS SAND
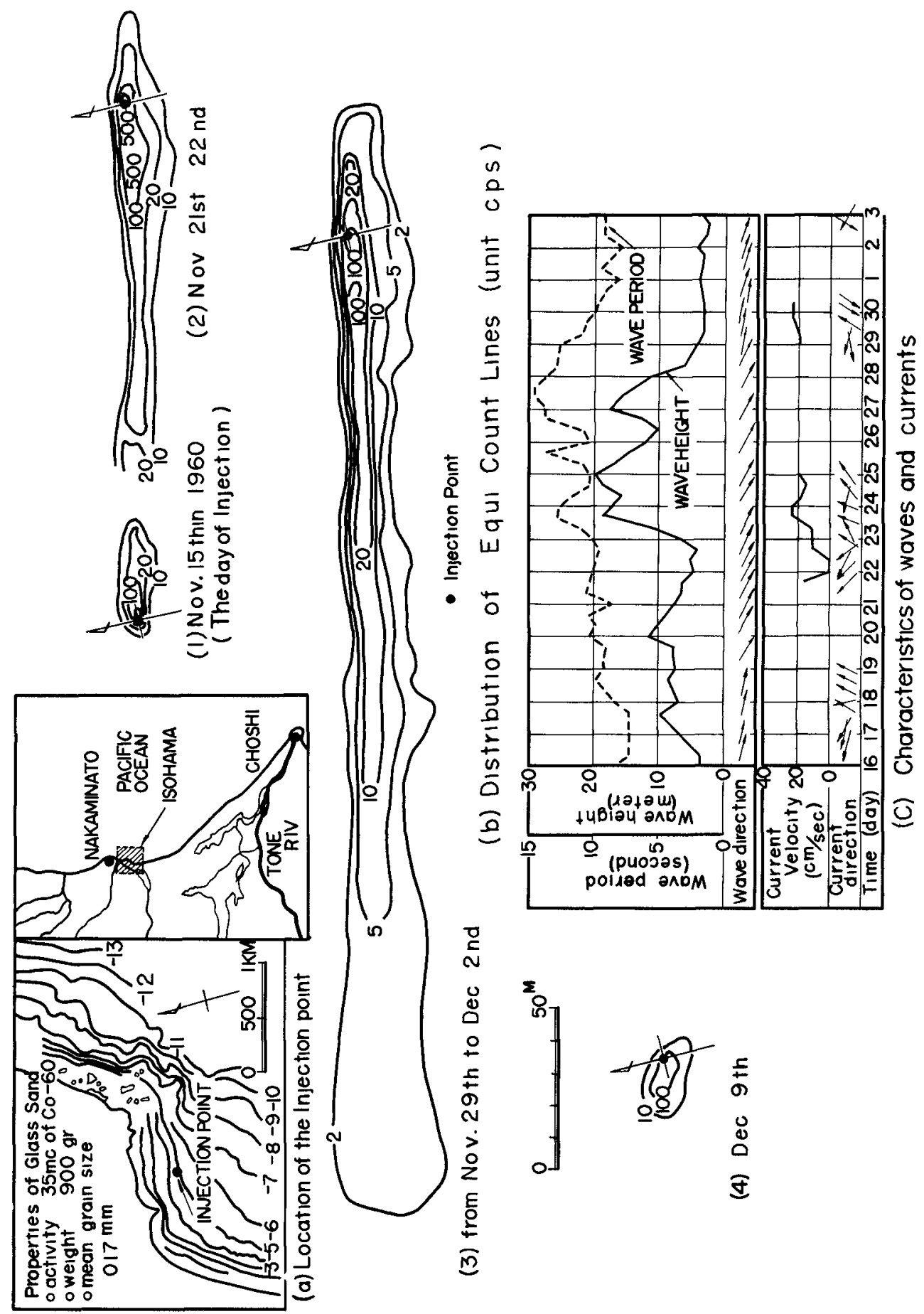

Fig. 4. Experi.nent at 4.5 meters deep of Isohama. 


\section{COASTAL ENGINEERING}

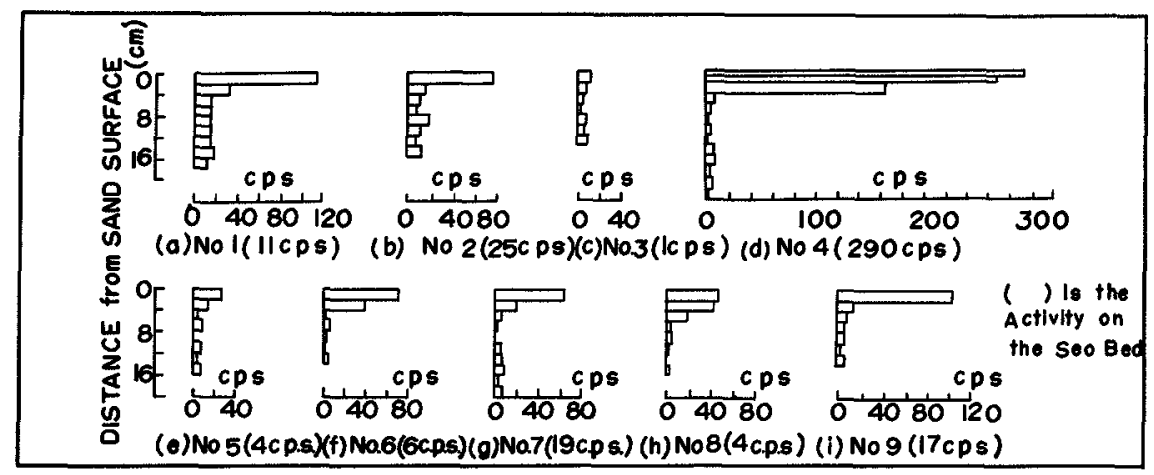

Fig. 5. Vertical Distribution of radioactive glass sand.

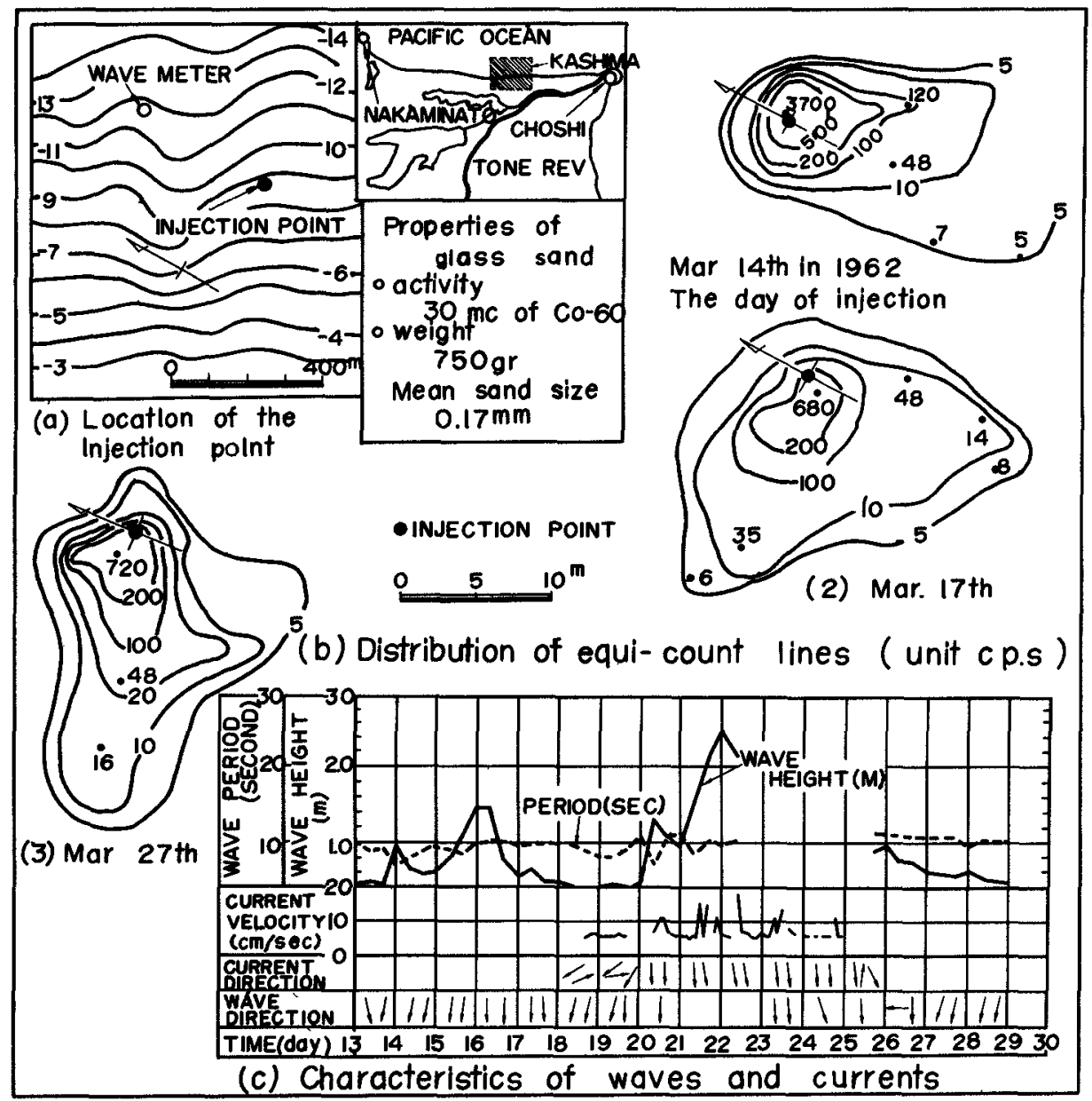

Fig. 6. Experiment at 9 meters deep of Kashima. 
A STUDY OF CRITICAL DEPTH AND MODE OF SAND MOVEMENT USING RADIOACTIVE GLASS SAND
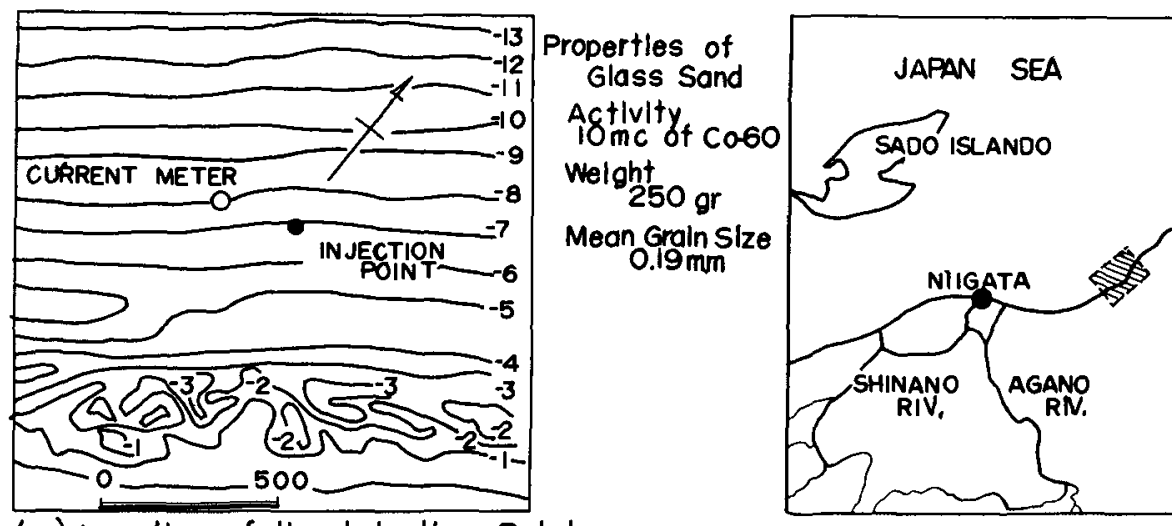

(a) Location of the Injection Point

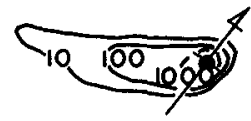

(1) July 15th in 1962

(The day of injection)
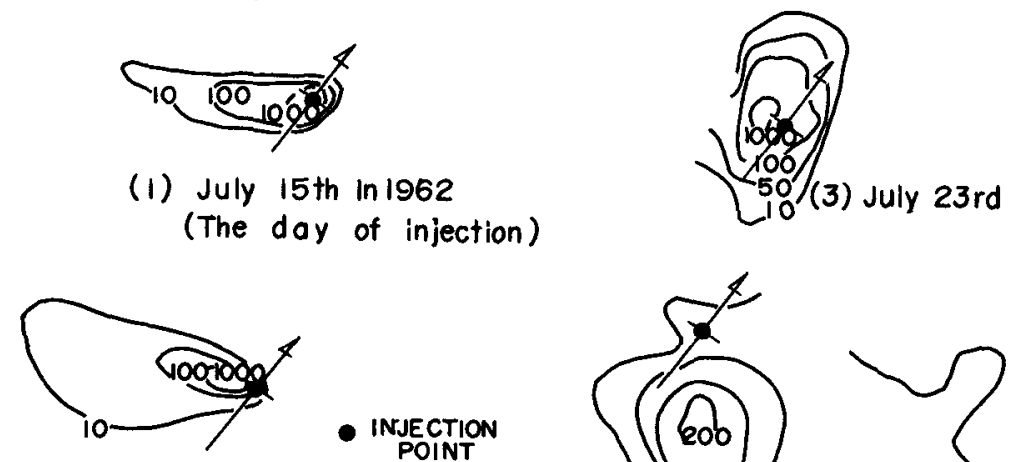

(2) July $18^{\text {th }}$
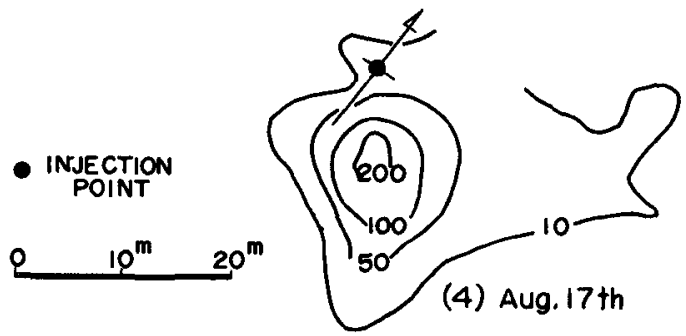

(b) Distribution of Equi $\underset{\text { Count }}{\text { unit } C D S)}$ Lines

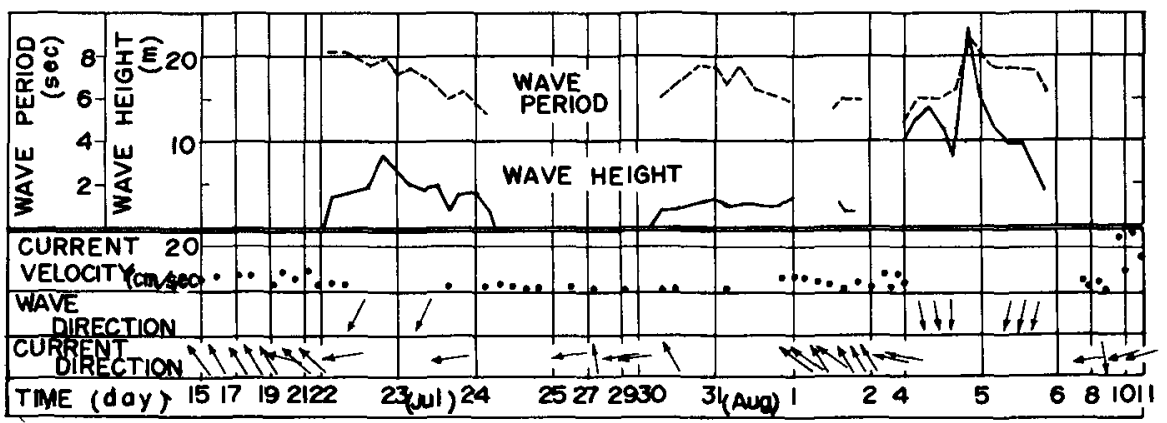

(c) Characteristics of Waves on the 10 meters Depth and Currents

Fig. 7. Experiment at 7 meters deep of Niigate. 
COASTAL ENGINEERING

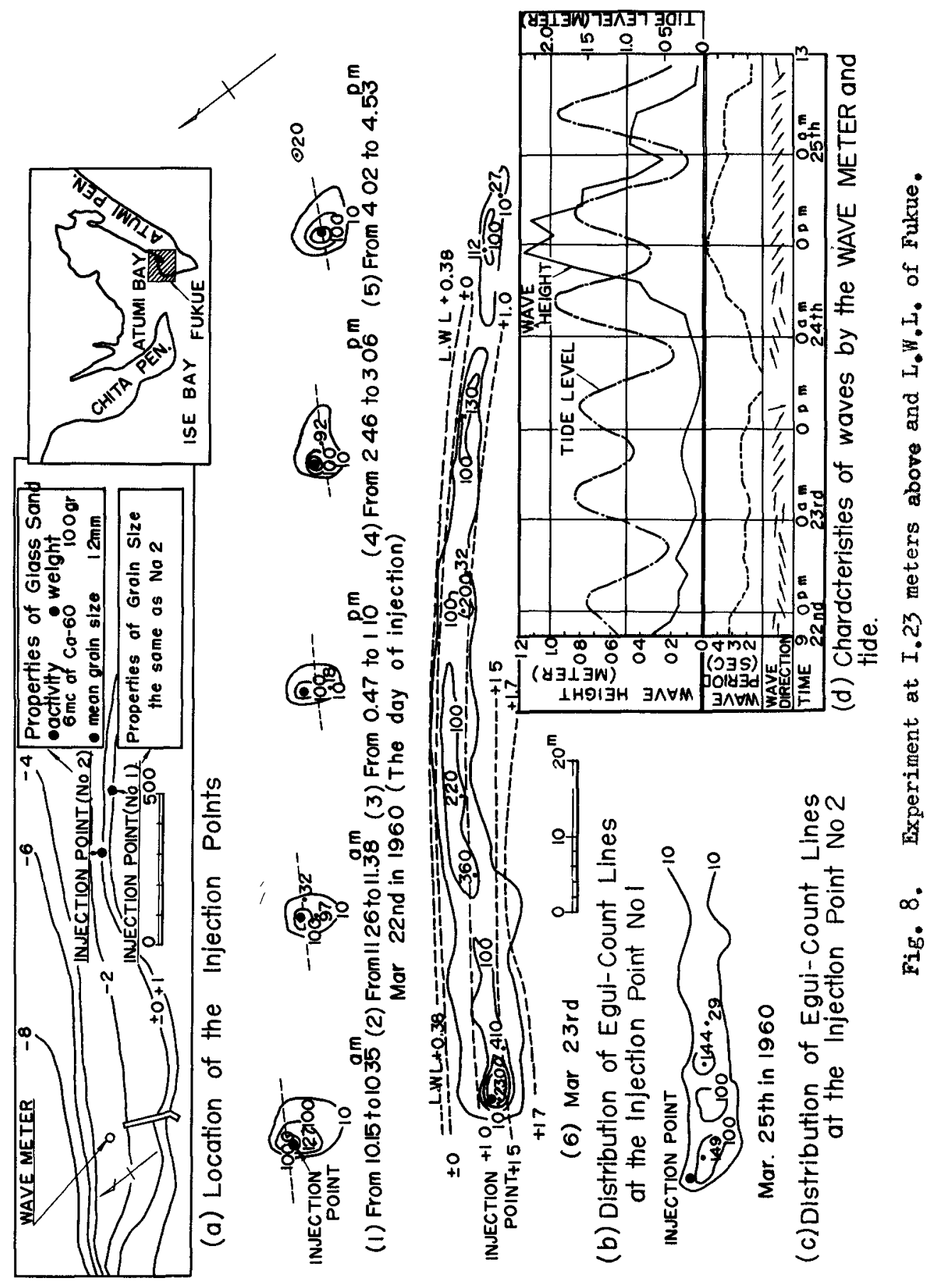




\section{A STUDY OF CRITICAL DEPTH AND MODE OF SAND MOVEMENT USING RADIOACTIVE GLASS SAND}

and all equi-count lines streched shoreward.

The characteristics of the sand movement in the of fshore zone From the above-mentioned and authors' other experiments, it is considered as follows on the sand movement in offshore zone.

(1) On the coast of open sea, the direction of sand transport coincides with the wave direction in general, and where the tidal currents is beyond one or two knot in velocity it coincides with the direction of tidal currents.

(2) If the wave height is small on the coast of open sea, the bottom sand tends to move in the direction different from the wave, that is, a part of sand suspended by wave flows in the same direction as tidal currents. Therefore, in the point of about 10 meters deep, sand has a tendency to be transported in the direction of tidal currents as shown in Figure 6 , and at the point of about 4 to 6 meters deep it tends to move in the opposit direction to the waves as shown in Figure 5 and 7.

(3) When most of sand has to be transported in the direction of wave, if there is a current of the direction different from the wave, a part of sand tends to be moved to the direction of current.

( 4 ) Considering from the vertical distribution of glass sand at Isohama, it would be assumed that the layer thicioness of sand movement is the same degree as the height of ripple on the sea bottom.

\section{THE SAND MOVEMENT IN THE SURF ZCNE}

As the examples of the field experiment in the surf zone, results of Fukue and Kashimanada Coast are shown in Figure 7 and 8 , respectively.

The experiment at 1.23 meters above $L$. W. L. of Fukue Coast Fukue Coast is on the Atsumi Bay, where $M_{0} \mathrm{H}_{0} \mathrm{I}_{0}$ and $\mathrm{H}_{0} \mathrm{~W}_{0} \mathrm{~L}_{0}$ are 1.90 and 2.20 meters above L.W.I. respectively, and the wave height in stormy season is only about one meter. The result of tracing at the point of 1.23 meters above $L_{0} . W_{0} I_{\text {. }}$ is shown in Figure 8. On the injection day, the incident angle of breakers against the coast line was about $30^{\circ}$ at $10 \mathrm{a} . \mathrm{m}$. and became gradually larger to $60^{\circ}$ at $2 \mathrm{p} . \mathrm{m}_{.}$; this seems to be

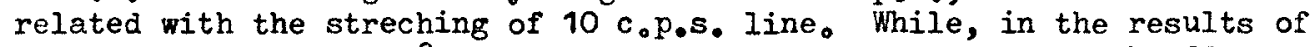
measurement of about 18 hours after the last measurement of the 22nd, most of glass sand distributed in long and narrow between L.W.L. of $8.35 \mathrm{p} . \mathrm{m} .22 \mathrm{nd}$ and $\mathrm{H}_{0} \mathrm{H}_{\text {. L }}$ of $3.30 \mathrm{a} . \mathrm{m} .23 \mathrm{rd}$, while the wave height decreased gradually after the last measurement of the $23 \mathrm{rd}$. This shows clearly that the influence of tidal level on sand movement in the forshore zone is remarkable, this is, the glass sand suspended by the breaking of waves was transportel on the beach in the zig-zag form, because waves became to break near the injection point with the rising of tidal level from the night of the 22 nd to the morning of the $23 \mathrm{rd}$.

The experiment on the point of L.W.L. at Fukue Coast The glass 


\section{COASTAL ENGINEERING}

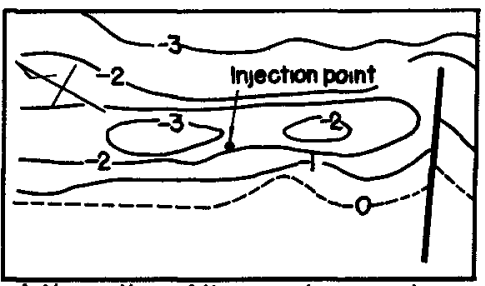

(a)Location of the injection point

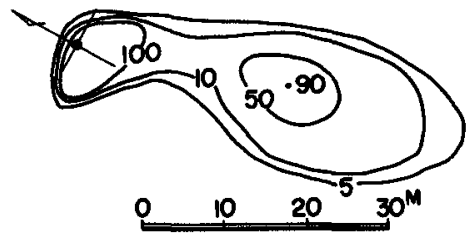

(1) Jun 29th in 1962

(The day of injection)

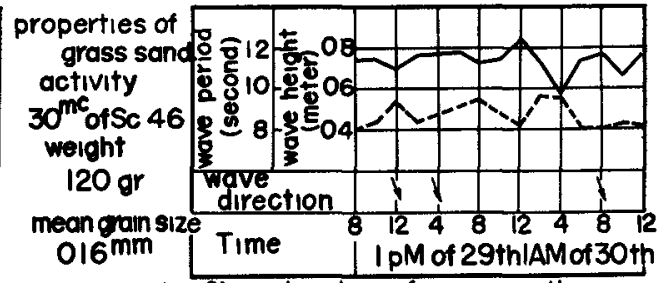

(c) Charactenstics of waves on the 10 meters depth

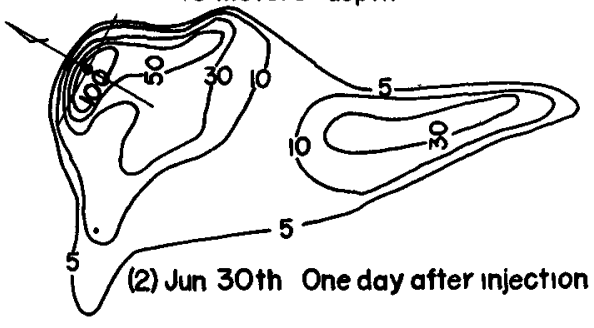

(b) Distribution of equ count lines unit $c p s$

Fig. 9. Experiment at 2.3 meters deep of Kashima.

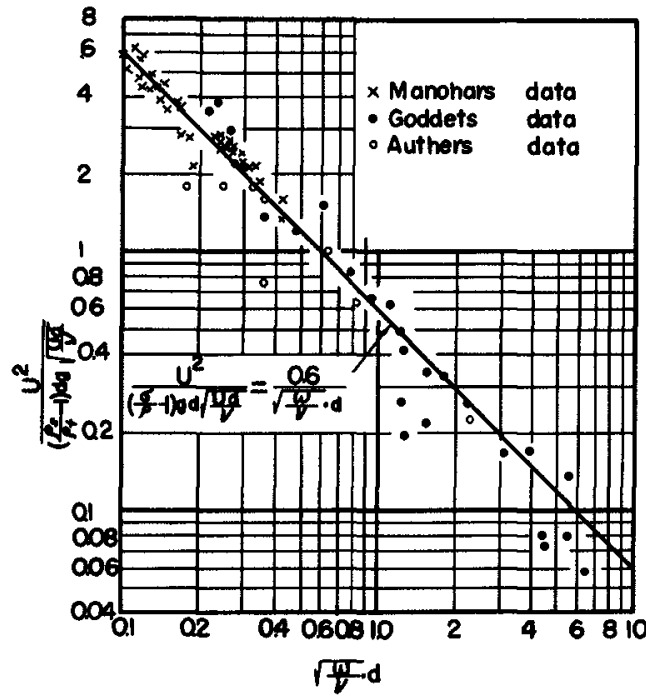

Fig. Io. The begining of general movement by laboratory test.

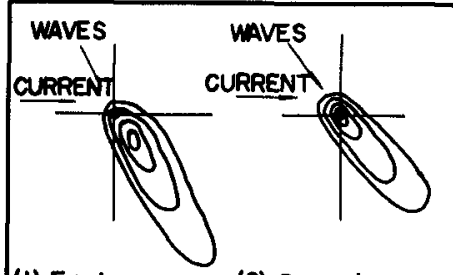

(1) First group (2) Second group

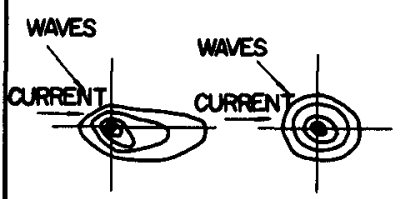

(3)Thurd group (4) Fourth group

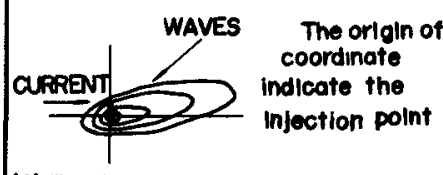

(4) Fourth group

Fig. II. Classification of the distribution of radioactive glass sand. 


\section{A STUDY OF CRITICAL DEPTH AND MODE OF SAND MOVEMENT USING RADIOACTIVE GLASS SAND}

sand was injected about $4 \mathrm{p}_{\bullet} \mathrm{m}_{\text {. }}$ of March $23 \mathrm{rd}$, when the sea was very calm and the glass sand could be seen to be dropped in a point. This point was below water level during this experiment, and acted by breaking wave. The result. of measurement in two days after injection is shown in Figure $8-(\mathrm{c})$, where the higher equi-count lines strech in the direction of SSW and the lower equi-count lines strech to

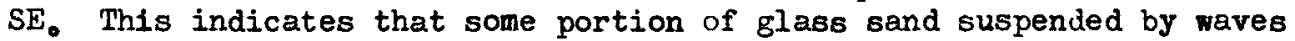
was transported by littotal current when glass sand was pushed in the direction of waves.

The experiment at Kashimanada Coast The glass sand was injected inside of the longshore bar when the wave height was comparatively small. The result of measurements is shown in Figure 9, where the glass sand distributed in the direction of both perpendicular and parallel to coastal line like the results of experiment at $I_{0} W_{0} I_{0}$ of Fukue Coast.

Tha characteristics of the sand movement in the surf zone As mentioned above, authors have only a few data of the experiment in the inshore zone and, also all of them are taken when the wave height is small. Therefore, authors can not present clearly the characteristics of sand movement, but the following properties would be estimated on the base of the above mentioned examples.

(1) In the inshore zone, the littoral currents and waves after breaking are main factors of the sand movement. The sand on the sea bottom is flushed by breaking waves in their direction, and at the same time, the sand disturbed by breaking waves transported along the coast in the direction of littoral currents.

(2) In the foreshore zone, the uprush and backwash of waves and the rising of tidal level mainly control the sand movement. The sand in the foreshore zone has a remarkable tendency to be transported in parallel to the coast line, even when the wave height is small.

THE CRITICAL DEPTH OF SAND TRANSPORT OBTAINED FROM THE FIELD EXPERIMENT USING RADIOACTIVE GIASS SAND

\section{THE CRITICAL DEPTH OF SAND MOVEMENT DUE TO WAVES}

It is known experimentally that the sand grains begin to move when the force of waves acting on the sea bottom become a certain value and is transported by waves through each steps of initial movement, general movement and initiation and disappearance of ripples with the increase of wave action. There are different experimental equations as to the initiation of above steps, but authors also derived the equation for the initiation of general Movement from laboratory experiments.

Sand grains start to move when the drag force of waves acting on sand grains overtakes the friction force due to gravity. At this moment the following equation 18 given.

$$
\left\{\left(\frac{\sigma}{\rho}-1\right) g d^{3} \frac{\pi}{6} \tan \varphi\right\}=K \frac{\pi}{8} C_{D} U_{b}^{2} d^{2},
$$




\section{COASTAL ENGINEERING}

where $\sigma=$ snecific gravity of sand grains, $\rho=$ specific gravity of fluid, $\mathrm{g}=$ acceleration due to gravity, $\mathrm{d}=$ diameter of $\operatorname{sand}$ grain, $\varphi=$ angle of repose, $C_{D}=$ coefficient of drag, $U_{b}=$ maximum horizontal particle velocity due to wave at the top of sand grain, and $K=$ constant.

$U_{b}$ is expressed as $U \cdot f\left(\sqrt{\frac{\omega}{\nu}} d\right)$ in the boundary layer, where $U$ is the maximum velocity due to wave in the outside of boundary layer, $\nu$ the kinematic viscosity of fluid and $\omega$ angular velocity of water particle. Therefore, assuming that the coefficient of drag $C_{D}$ is inversely proportional to the square root of the Reynold's Number Ud/ $/ \nu$, the above equation can be modified as

$$
\frac{u^{2}}{\left(\frac{\sigma}{\rho}-1\right) g d \sqrt{u d / \nu}}=K^{\prime} \cdot f(\sqrt{\omega / \nu} d) \text {. }
$$

In order to make clear the value of constant $K^{\prime}$ and the form of the function $f(\sqrt{\omega /} d)$, the data of the experiments on the begining of general movement by authors', Manohor's and Goddet's experiments are plotted in Figure 10 with $U^{2} /\left(\frac{\sigma}{\rho}-1\right) g d \sqrt{U d / \nu}$ against $\sqrt{\omega / \nu} d$. From this figure, the following equation for the initiation of general movement is obtained.

$$
\frac{u^{2}}{\left(\frac{\sigma}{\rho}-1\right) g d \sqrt{u d / v}}=\frac{0.6}{\sqrt{\omega / \nu} d} .
$$

Substituting the above equation with $U=\frac{\frac{\pi}{T}}{\sinh \frac{H}{2 \pi} h}, \dot{\omega}=\frac{2 \pi}{T}$, and $T^{2}=\frac{2 \pi}{9} L_{0}$

$$
\frac{H}{L_{0}}=\left\{0.4243 \frac{2}{\pi}\left(\frac{\sigma}{\rho}-1\right)\right\}^{\frac{2}{3}}\left(d / L_{0}\right)^{\frac{1}{3}} \frac{\sinh }{\sinh } \frac{2 \frac{T}{\pi} h}{L}
$$

Or from $H / L_{0}=\left(H_{0} / L_{0}\right)(H / H), \sigma=2.65$ and $\rho=1.03$

$$
H_{0} / L_{0}=0.565\left(\frac{d}{L_{0}}\right) \sinh \frac{2 h}{L} \cdot \frac{H_{0}}{H}
$$

and

$$
H_{0} / L_{0}=\left(\sinh \frac{2 \pi h}{L_{0}}\right)^{-1}\left(\frac{H_{0}}{H}\right)^{-1}=0.565\left(\frac{d}{L_{0}}\right)^{\frac{1}{3}}
$$

where $H$ and $L$ are height and lenght of wave, and suffix 'o indicats the value of deep water wave.

In general, one of the most important problem in the construction of harbor on sandy coast is to extend breakwaters to the depth enough to prevent the entrance of harbor from shoaling. For this purpose, it is desirable to extend breakwaters to the depth obtained from equation (3), but it is unpractical. In the field experiment of the offshore zone mentioned previously, the glass sand of less than 0.3 millimeters in size was transported in the direction different from the wave when the height of waves was very small, and was mainly transported in the same direction as wave when it was little larger. Therefore, the depth at which sand starts to move remarkably in the same direction as that of waves would be thought to be one of criterion for the determination of depth to which breakwaters should be extended. Such a critical depth should be obtained from the results of field experiments.

THE CRITICAL DEPTH FOR SAND TO BEGIN TO MOVE IN THE DIRECTION OF WAVES

The distribution of radioactive glass sand in the offshore zone 


\section{A STUDY OF CRITICAL DEPTH AND MODE OF SAND MOVEMENT USING RADIOACTIVE GLASS SAND}

measured by authors are classified into the following four groups, as shown in Figure 11.

(1) The first group This is the case that the point of the maximum counts moves in the same direction as waves, and all equicount lines also extend in the same direction as waves. Such a distribution of glass sand indicates that the bottom material is completely transported by waves.

(2) The second group This is the case that the point of the maximum counts does not move, but all equi-count lines extend in the same direction as waves. In this case, the distribution of equi-count lines is not wider than that of the first group.

(3) The third group This is the case that the point of the maximum couts does not move and only a part of equi-count lines extends in the same direction as waves. This group also contains the case that the counts "decrease remarkably as a whole, despite the distribution of equi-count lines scarecely changes.

(4) The fourth group This is the case that the distribution of equi-count lines remains unchanged and also the counts do not decrease so much. The case that the equi-count lines extend in the same direction as tidal currents and the direction opposite to waves is also contained in this group.

Then, classifing the glass sand distributions of our experiments into these four groups, $H_{0} / L_{0} \cdot\left(\sinh \frac{2 \pi h}{L}\right)^{-1}\left(\frac{H_{0}}{H}\right)^{-1}$ and $d / L_{0}$ in Equation (4) are calculated for each distribution of which the results are shown in Table-1. The wave period $\mathrm{T}$ and wave height $\mathrm{H}$ used in this calculation are those of the maximum significant waves on the injection point during the successive measurement of distribution and the depth $h$ is the mean water depth of the injection point. $H_{0}$ and $L_{0}$ are those for the equivalent deep water wave of $H$ and $T$. In Figure 12, the data of Table 1 are plotted with $H_{0} / L_{0}\left(\sinh \frac{2 \pi h}{L}\right)^{-1}\left(H_{0} / H\right)^{-1}$ s ordinate and $d / L_{0}$ as abscissa. In this figure, the transition from the second group to the third group is shown by the following equation.

$$
\frac{H_{0}}{L_{0}}=1.35\left(\frac{d}{L_{0}}\right)^{\frac{1}{3}} \sinh \frac{2 \pi h}{L}\left(\frac{H_{0}}{H}\right) \text {, }
$$

which expresses the relation of sand size, characteristics of wave and water depth when the bottom materials start to move in the same direction as waves. Equation (4) for the initiation of general movement by laboratory experiments is also shown in this figure. All the points of the third group and a few points of the fourth group are distributed between the curves of Equation (4) and (5) and the other points of the fourth below the curve of Equation (4). Therefore, it is considered that Equation (4) coincides with the results of the field experiment.

THE MODE OF SAND MOVEMENT BY MODEL EXPERIMENT

SAND MOVEMENT IN THE OFFSHORE ZONE 
Table $I_{0}$ The value of $H_{0} / L_{0}\left(\sinh \frac{2 \pi h}{L}\right)^{-1}\left(H_{0} / H\right)^{-1}$ and $\alpha / L_{0}$ for each distribution of radioactive glass sand.

No. Coast Group Dote $d(m m) h(m) T(\sec ) H_{0}(m) \frac{H_{0}}{L_{0}} \frac{d}{L_{0}} \times 10^{-6}\left(\frac{H_{0}}{L_{0}}\right)\left(\frac{H_{0}}{H}\right)^{-1}\left(\sinh \frac{2 \pi h}{L_{h}}\right)^{-1}$ Remorks

\begin{tabular}{|c|c|c|c|c|c|c|c|c|c|c|c|}
\hline $\begin{array}{ll}1 & \text { Tomakomol } \\
2 & \\
3 & \\
4 & \\
5 & \\
6 & \\
7 & \\
8 & \\
9 & \\
10 & \\
11 & \\
12 & \\
13 & \\
14 & \end{array}$ & $\begin{array}{l}\text { Ist Gr } \\
\text { 2nd } \\
\text { 3rd } \\
4 \text { th } \\
\text { 2nd } \\
\text { ist } \\
\text { 2nd } \\
\text { 3rd } \\
\text { 3rd } \\
\text { 3rd } \\
\text { 2nd } \\
\text { 2nd } \\
\text { 3rd } \\
4 \text { th }\end{array}$ & $\begin{array}{l}629 \\
714 \\
724 \\
520 \\
521 \\
5.27 \\
63 \\
613 \\
623 \\
83 \\
813 \\
1111 \\
1119 \\
1130\end{array}$ & $\begin{array}{l}\text { to } 71354 \\
\text { to } 72454 \\
\text { to } 81154 \\
\text { to } 52155 \\
\text { to } 52755 \\
\text { to } 60355 \\
\text { to } 61355 \\
\text { to } 62355 \\
\text { to } 7755 \\
\text { to } 81355 \\
\text { to } 9855 \\
\text { to } 111956 \\
\text { to } 113056 \\
\text { to } 122456\end{array}$ & $\begin{array}{l}017 \\
0117 \\
0117 \\
012 \\
012 \\
012 \\
012 \\
012 \\
012 \\
012 \\
012 \\
012 \\
012 \\
012 \\
012 \\
012 \\
012\end{array}$ & $\begin{array}{l}38 \\
38 \\
38 \\
70 \\
70 \\
70 \\
70 \\
70 \\
70 \\
100 \\
100 \\
100 \\
100 \\
100\end{array}$ & $\begin{array}{r}50 \\
80 \\
60 \\
80 \\
60 \\
100 \\
50 \\
70 \\
50 \\
60 \\
150 \\
90 \\
100 \\
100\end{array}$ & $\begin{array}{l}10 \\
08 \\
17 \\
04 \\
16 \\
26 \\
18 \\
12 \\
14 \\
13 \\
26 \\
16 \\
13 \\
06\end{array}$ & $\begin{array}{l}00256 \\
00087 \\
00362 \\
00044 \\
00285 \\
00162 \\
00460 \\
00158 \\
00359 \\
00231 \\
00074 \\
00125 \\
00084 \\
00039\end{array}$ & $\begin{array}{l}436 \\
195 \\
303 \\
131 \\
213 \\
0767 \\
308 \\
158 \\
308 \\
213 \\
342 \\
075 \\
077 \\
077\end{array}$ & $\begin{array}{l}00241 \\
00166 \\
00286 \\
00509 \\
00216 \\
00298 \\
00245 \\
00157 \\
00191 \\
001265 \\
00185 \\
00141 \\
00113 \\
00052\end{array}$ & \\
\hline $\begin{array}{l}15 \\
16 \\
17 \\
18 \\
19 \\
20 \\
21 \\
22 \\
23 \\
24\end{array}$ & $\begin{array}{l}\text { 4th } \\
4 \text { th } \\
4 \text { th } \\
\text { 2nd } \\
\text { ist } \\
\text { ist } \\
\text { ist } \\
4 \text { th } \\
4 \text { th } \\
4 \text { th }\end{array}$ & $\begin{array}{ll}1 & 21 \\
126 \\
128 \\
126 \\
129 \\
210 \\
223 \\
916 \\
928 \\
1010\end{array}$ & $\begin{array}{l}\text { to } 12658 \\
\text { to } 12858 \\
\text { to } 21158 \\
\text { to } 12958 \\
\text { to } 21058 \\
\text { to } 22358 \\
\text { to } 31158 \\
\text { to } 92057 \\
\text { to } 101057 \\
\text { to } 102557\end{array}$ & $\begin{array}{l}025 \\
025 \\
0225 \\
0217 \\
017 \\
017 \\
017 \\
017 \\
025 \\
025 \\
025\end{array}$ & $\begin{array}{l}110 \\
110 \\
110 \\
40 \\
40 \\
40 \\
40 \\
105 \\
105 \\
105\end{array}$ & $\begin{array}{l}50 \\
50 \\
50 \\
50 \\
50 \\
60 \\
60 \\
50 \\
120 \\
40\end{array}$ & $\begin{array}{l}13 \\
13 \\
12 \\
13 \\
12 \\
13 \\
16 \\
10 \\
09 \\
09\end{array}$ & $\begin{array}{l}00334 \\
00334 \\
00308 \\
00334 \\
00308 \\
00231 \\
00308 \\
00254 \\
00039 \\
00344\end{array}$ & $\begin{array}{l}641 \\
641 \\
641 \\
436 \\
436 \\
303 \\
303 \\
641 \\
112 \\
100\end{array}$ & $\begin{array}{l}00099 \\
00099 \\
00091 \\
00303 \\
00299 \\
00285 \\
00380 \\
00087 \\
00065 \\
00047\end{array}$ & $\begin{array}{r}\text { Flo. } 3(2) \\
(3) \\
(4)\end{array}$ \\
\hline 25 Fukue & 4 th & & & 03 & 30 & 40 & 09 & 00348 & 120 & 00275 & \\
\hline $\begin{array}{l}26 \text { Isohamo } \\
27 \\
28 \\
29 \\
30 \\
31 \\
32 \\
33 \\
34\end{array}$ & $\begin{array}{l}\text { Ist } \\
\text { ist } \\
\text { Ist } \\
4 \text { th } \\
\text { 2nd } \\
3 \text { rd } \\
4 \text { th } \\
4 \text { th } \\
\text { Ist }\end{array}$ & $\begin{array}{ll}1116 \\
1122 \\
1129 \\
120 \\
121 \\
23 \\
210 \\
120 \\
121\end{array}$ & $\begin{array}{l}\text { to } 11.2260 \\
\text { to } 112960 \\
\text { tol2 } 960 \\
\text { to } 12161 \\
\text { to } 2361 \\
\text { to } 21061 \\
\text { to } 22361 \\
\text { to } 121.61 \\
\text { to } 2261\end{array}$ & $\begin{array}{ll}0 & 17 \\
0 & 17 \\
0 & 17 \\
0 & 17 \\
0 & 17 \\
0 & 17 \\
0 & 17 \\
0 & 17 \\
0 & 17\end{array}$ & $\begin{array}{l}55 \\
55 \\
55 \\
100 \\
100 \\
100 \\
100 \\
55 \\
55\end{array}$ & $\begin{aligned} 100 \\
110 \\
110 \\
90 \\
130 \\
80 \\
130 \\
90 \\
130\end{aligned}$ & $\begin{array}{l}13 \\
23 \\
26 \\
04 \\
24 \\
15 \\
10 \\
04 \\
27\end{array}$ & $\begin{array}{l}00084 \\
00120 \\
00156 \\
00030 \\
00090 \\
00161 \\
00037 \\
00033 \\
00101\end{array}$ & $\begin{array}{l}108 \\
090 \\
090 \\
135 \\
0647 \\
185 \\
0647 \\
135 \\
0647\end{array}$ & $\begin{array}{l}00164 \\
00300 \\
00388 \\
00034 \\
00189 \\
00139 \\
00074 \\
00060 \\
00324\end{array}$ & Flg. $\left.4 \begin{array}{l}(2) \\
(3 \\
(4)\end{array}\right)$ \\
\hline $\begin{array}{l}35 \\
36 \\
37 \\
38 \\
\end{array}$ & $\begin{array}{l}\text { 3rd } \\
\text { 2nd } \\
\text { 2nd } \\
\text { 2nd } \\
\text { 3rd } \\
4 \text { th } \\
\text { 3rd } \\
\text { ist } \\
\text { Ist } \\
\text { 2nd }\end{array}$ & $\begin{array}{ll}17 \\
18 \\
112 \\
314 \\
317 \\
314 \\
317 \\
429 \\
430 \\
428\end{array}$ & $\begin{array}{l}\text { to } 1862 \\
\text { to } 11262 \\
\text { to } 12662 \\
\text { to } 31762 \\
\text { to } 32762 \\
\text { to } 31762 \\
\text { to } 32762 \\
\text { to } 43062 \\
\text { to } 51062 \\
\text { to } 51062\end{array}$ & $\begin{array}{l}017 \\
017 \\
017 \\
017 \\
017 \\
017 \\
2.8 \\
28 \\
015 \\
015 \\
015\end{array}$ & $\begin{array}{l}80 \\
80 \\
80 \\
100 \\
100 \\
100 \\
100 \\
60 \\
60 \\
120\end{array}$ & $\begin{array}{l}110 \\
100 \\
120 \\
120 \\
100 \\
100 \\
100 \\
80 \\
80 \\
80\end{array}$ & $\begin{array}{l}071 \\
14 \\
15 \\
15 \\
26 \\
15 \\
26 \\
13 \\
17 \\
17\end{array}$ & $\begin{array}{l}00038 \\
00092 \\
00065 \\
00065 \\
00165 \\
00095 \\
00165 \\
00142 \\
00190 \\
00190\end{array}$ & $\begin{array}{l}0901 \\
109 \\
0759 \\
0759 \\
109 \\
178 \\
178 \\
163 \\
163 \\
163\end{array}$ & $\begin{array}{l}0007 \\
00148 \\
00147 \\
00137 \\
00134 \\
00224 \\
00127 \\
00187 \\
00187 \\
00251 \\
00137\end{array}$ & Fig. $6\left(\begin{array}{l}2) \\
(3)\end{array}\right.$ \\
\hline 5 Nilgata & $\begin{array}{l}\text { Ist } \\
\text { 3rd } \\
\text { Ist }\end{array}$ & $\begin{array}{l}718 \\
718 \\
723\end{array}$ & $\begin{array}{l}\text { to } 81762 \\
\text { to } 72362 \\
\text { to } 81762\end{array}$ & $\begin{array}{l}016 \\
019 \\
019\end{array}$ & $\begin{array}{l}90 \\
75 \\
75\end{array}$ & $\begin{array}{l}90 \\
80 \\
90\end{array}$ & $\begin{array}{l}24 \\
093 \\
24\end{array}$ & $\begin{array}{l}00190 \\
00093 \\
00190\end{array}$ & $\begin{array}{l}128 \\
194 \\
154\end{array}$ & $\begin{array}{l}00236 \\
00079 \\
00267\end{array}$ & 10.7 (3) \\
\hline
\end{tabular}




\section{A STUDY OF CRITICAL DEPTH AND MODE OF SAND MOVEMENT USING RADIOACTIVE GLASS SAND}

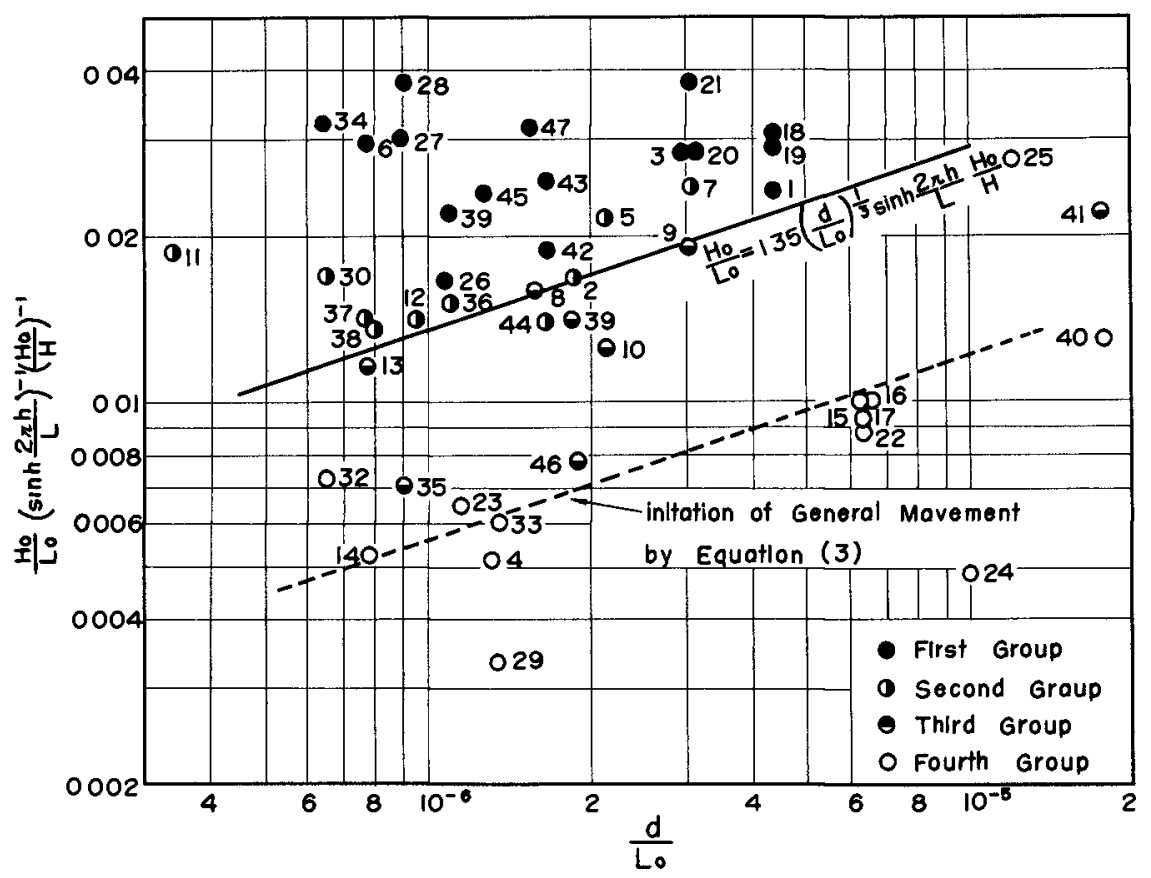

Fig. I2. Relation between $\frac{H_{0}}{L_{0}} \cdot\left(\sinh \frac{2 \pi h}{L}\right)^{-1} \cdot\left(\frac{H_{0}}{H}\right)^{-1}$ and $d / L_{0}$ for each distribution of radioactive glass sand.

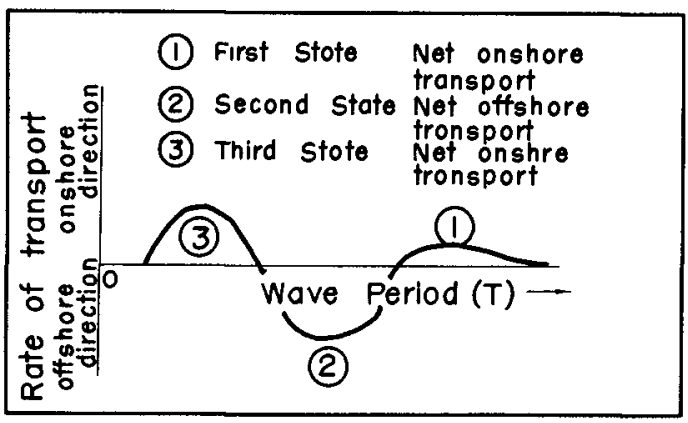

Fig. I3. Three states of sand transport. 


\section{COASTAL ENGINEERING}

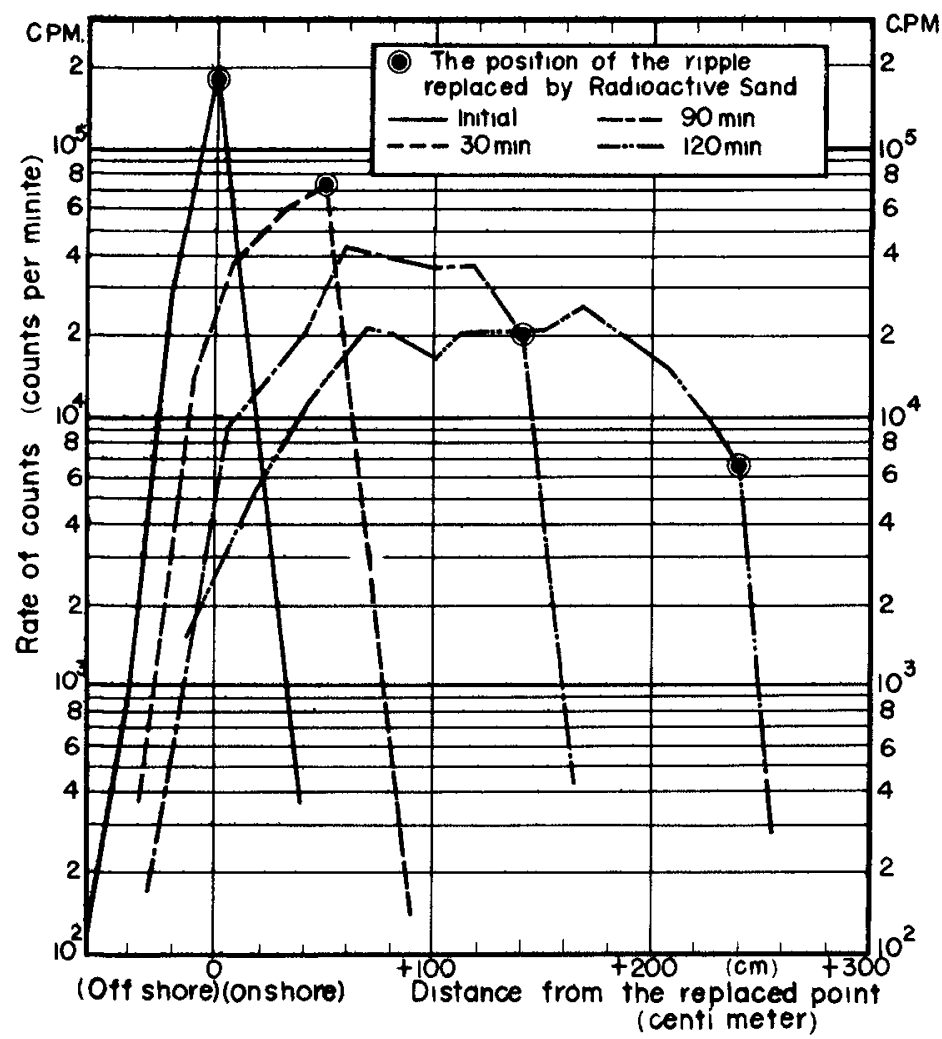

Fig. I4. Time change of radioactivity distribution in the first state.

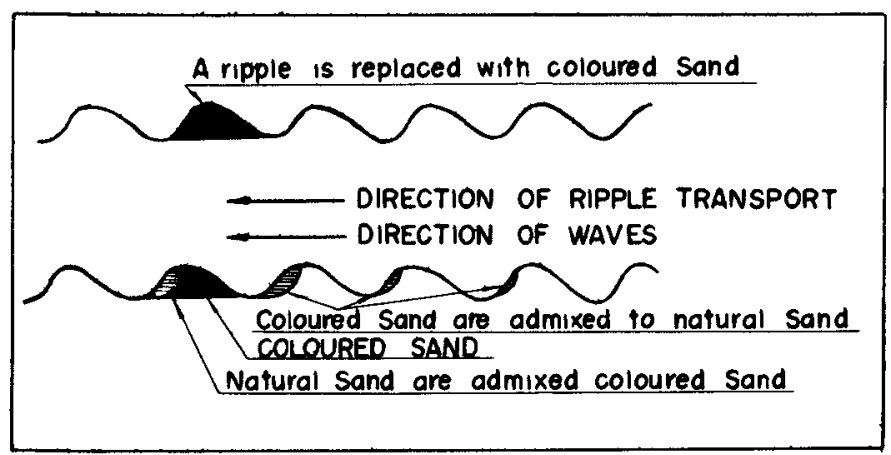

Fig. 15. Sketch of dyed sand movement. 


\section{A STUDY OF CRITICAL DEPTH AND MODE OF SAND MOVEMENT USING RADIOACTIVE GLASS SAND}

In the channel experiment of horizontal bed with constant depth, as the wave period gradually decrease, bed sand is at first moved onshore (the first state), and then moved offshore (the second state). As the period further decrease, sand is again moved onshore ( the third state ) and finally stops moving. Such a state of movement is sketched in Figure 13.

When the grain size is large, there appears only the first state. then the grain size is small, all of these state apper. In order to find which state the movement of glass sand in our field experiment belongs to, authors performed some model test using glass sand containing Cr-51.

\section{EXPERIMENTAL PROCEDURES}

The experiment were conducted in a glass walled channel 50 centimeters wide, 80 centimeters deep and 40 meters long, with a flap wave generator at one end a seaward slope 1:10 at other end. Sand was placed in five centimeters thick on the horizontal bed between 8 and 17 meters from the wave plate. The water depth was 40 centimeters to the sand surface through all test runs.

In each run, after ripples were fully developed a ripple was replaced with the radioactive glass sand of $\mathrm{C} r-51$ or dyed sand, of which the movement due to waves was traced. Cr-51 has the half life of 27 days and emits only soft $\gamma$ - ray of $0.3 \mathrm{MeV}$. Only a ripile was replaced because it was seen by preliminary tests that sind particles moved by waves were only portions forming ripples. The radloactive glass sand was traced with the watertight scintillation tube fixed on the carriage moving on the channel. The lower end of the tube always kept 5 centımeters above the crest of each ripple.

\section{PRESLNTATION AND DISCUŚ́ION OF RESULTS}

An example of time change of distribution of radioactive glass sand in the first state is show in Figure 14, where the distances from the original situation of ripple crest replaced by radioactive glass sand are shown in abscissa, taking posituve in the direction of wave propagation and the measured counts per minute or second are shown in ordinate. And also, the situation of the crest of the replaced ripple in each measurement is shown with double c1rcle in the same figure.

From Figure 14 it is clear that the glass sand particle are not transported beyond the replaced ripple and most of them is left behind it. This depends, as known by many other experiments, on the phenomena that when the crest of the wave passes over ripple, sand particles in surface layer move up on the offshore slope of it and at the same time a swirl of water is generated on the onshore slope of the ripple, and when the trough of the wave passes over it, sind particles picked up by the swirl move back to the offshore direction. This mode of sand movement is also clear by Figure 15 showing the distribution of dyed sand replaced for a ripple. The ripple replaced by dyed sand is graaually lightened from its onshore slope by sand transported from the 
COASTAL ENGINEERING
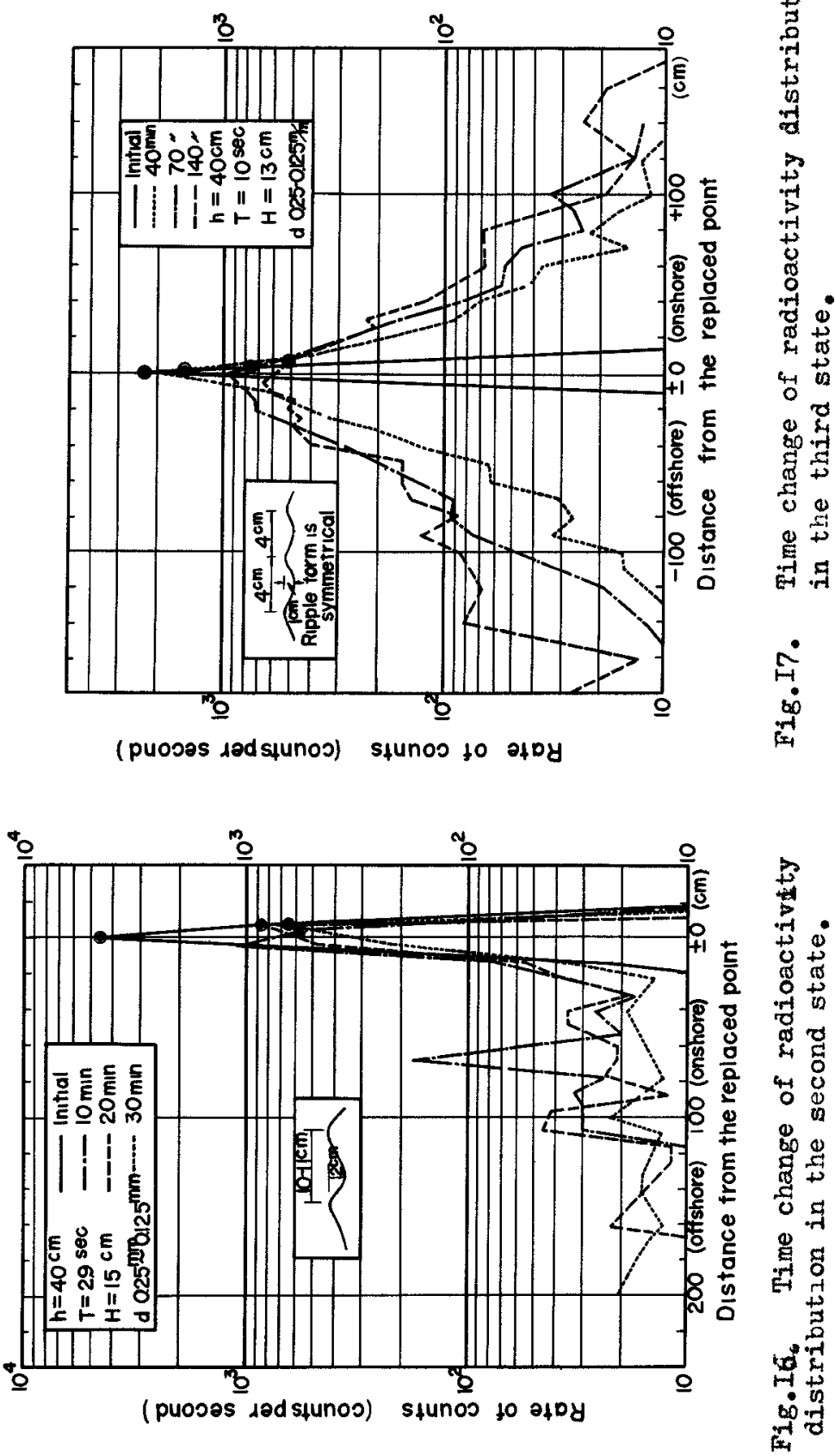


\section{A STUDY OF CRITICAL DEPTH AND MODE OF SAND MOVEMENT USING RADIOACTIVE GLASS SAND}

onshore side ripples and of fshore side ripples are colored mainly from its onshore side by sand from the onshore slope of the replaced ripple. Accordingly, sand is not so much supplied to the offshore of ripples, so that ripple always move shoreward, but in the first state the volume of the suspending sand transported seaward is less than that transported shoreward along the of fshore slope of ripples, so that the direction of net sand transport is shoreward.

On the contrary, in the second state, though ripples move slowly shoreward, the volume of sand suspended and transported seaward is more than that transported along the seaward slope of ripples, so that the direction of net sand transport is seaward. An example of the distribuion of glass sand in such a case is shown in Figure 16.

An example of the third state is shown in Figure 17. The remarkable characteristics of this state is for glass sand to be transported beyond the replaced ripple. In this case, the form of ripple is almost symetrical and swirls of water generate not only when the crest passes but also when the trough of the wave passes on the ripple, so that sand is suspended also shoreward beyond the ripple. In Figure 17, as the wave height is very small, net sand transport is almost zero, but if the wave height is large, the suspending sand transported shoreward would increase and in this result the net sand transport would become shoreward.

From the fact that the situation of the maximum counta in generally deviats seaward from the center of the distribution of equi-count lines in the field experiment, the mode: of glass sand movement in of fshore zone is possibly considered to be the same as that of the third state in this model test. Therefore, Equation (5) showing the begining of the onshore sand transportation may be also the equation presenting the transition from the second state to the third state in this model test. Accordingly in the field, the sand on the sea bed would be assumed to be transported in the mode of the second state when wave height is very small and in the mode of the third state when wave height becomes a little larger

The above-described properties of sand movement have been derived from a few kinds of field and model experiment, so that there may be some questionable points in them, and also many points remain not clear. Authors intend to complemented and make clear them further many experiments.

\section{REFERENCES}

Madhav Manohar ( 1955 ). Mechanics of bottom sediment movement due to wave action: Tech. Memo. No.75, Beach Erosion Board, Corps of Engineers U. S. Army.

J. Goddet ( 1960 ). Etude du debut d'entrainement des materiaux mobiles sous l'action de la houle: Ia Houllle Blanche, Vol.15 No.2. 